\title{
SCOPE OF PROMOTING INNOVATIONS IN RURAL ENTREPRENEURS AND ARTISANS IN WEST GODAVARI DISTRICT,ANDHRA PRADESH
}

\author{
Dr.K. Narendra Kumar ${ }^{1}$, Dr.K. Ganga Raju ${ }^{2}$ \\ ${ }^{1,2}$ Associate professor, Department of Management Studies, Vishnu institute of technology, Bhimavaram
}

\begin{abstract}
Rural Entrepreneurship development set as A challenge in this scenario of globalization. $68.84 \%$ of people live in rural areas of India, according to the 2011 Census. People in rural areas are suffering from unemployment and inadequate infrastructure facilities that can be addressed through rural entrepreneurs' growth. "Rural entrepreneurship can be defined as village -level entrepreneurship such as farming, business and acts as a powerful economic development factor." But these rural entrepreneurs are suffering from a number of problems, such as fear of risk, lack of capital, illiteracy and urban entrepreneurial rivalry. By providing job opportunities to citizens in cities, rural entrepreneurs raise the quality of life and buying power of people. In the sense of rural growth in India, this paper is an effort to explain the problems and challenges of rural entrepreneurship, artisans and potential suggestions to address the problems.
\end{abstract}

Keywords:

Rural Entrepreneurship, Digital media assistance, Marketing assistance, financial assistance

Article Received: 10 August 2020, Revised: 25 October 2020, Accepted: 18 November 2020

\section{Introduction}

Rural growth is more linked than ever before to entrepreneurship. Entrepreneurship is now seen as a strategic planning intervention by organisations and individuals who promote rural development that could boost the rural development process. Artisans in present scenario are facing so many problems . Entrepreneurship is recognised by the entrepreneurial tendency towards rural production as the central force of industrial growth and development without being wasted or frittered away by other factors of development. Recognizing entrepreneurship as a central driver for growth alone would not, however, lead to rural development and the promotion of rural enterprises. Moreover, an environment that allows entrepreneurship in rural areas is what is needed. The presence of such an ecosystem primarily depends on policies that foster rural entrepreneurship. The effectiveness of such strategies, in particular, relies on the contextual sense of entrepreneurship, i.e. what it is and where it originates from.

\section{OBJECTIVES}

The primary objective of this paper is to find out association between rural entrepreneurs and artisans regarding various aspects .
The secondary aim of this paper is to asses the rural entrepreneurship eco system in west Godavari district,Andhra pradesh

\section{RESEARCH METHODOLOGY}

The approach of the study describes the systematic way of finding the targets. It offers a straightforward direction for clear ideas to be achieved and reached. The following are the processes in which studies have gone through to draw the conclusion

\section{DATA COLLECTION:}

1. Primary source: The primary data was gathered with close-ended questions via a wellstructured questionnaire. The primary data is material that is obtained for the first time and thus unique in character.

2. Secondary source :The secondary sources are those that have already obtained by some other organisation, such as journals, blogs \& magazines, etc.

The sample size of this study is 100 and chi square analysis has been used in this study 


\begin{tabular}{|l|l|l|l|l|l|l|}
\hline Total Count & 9 & 22 & 30 & 39 & 100 \\
& $\begin{array}{l}\% \text { within } \\
\text { Digital media }\end{array}$ & $9.0 \%$ & $22.0 \%$ & $30.0 \%$ & $39.0 \%$ & $100.0 \%$ \\
\hline
\end{tabular}

Table 2.2 Results of chi square

\begin{tabular}{|l|l|l|l|}
\hline & Result & DF & Sig. (2-sided) \\
\hline "Pearson's- ChiSquare" & $0.452^{\mathrm{a}}$ & 3 & 0.929 \\
"Likeli -hood- Ratio" & 0.452 & 3 & 0.929 \\
"Linear relation" & 0.255 & 1 & 0.613 \\
"No. of Valid -Cases" & 100 & & \\
\hline
\end{tabular}

\section{Analysis:}

From the table, the calculated value was 0.452 , and the tabular value was $0.929 \chi$ is less than $\mathrm{p}$, hence $\mathrm{HO}$ is accepted
3) Ho: There is an relationship between rural entrepreneurs \& Artisans regarding Marketing Assistance

H1: There is no relationship between rural entrepreneurs \& Artisans regarding Marketing Assistance

Table 3.1 Cross tabulation of marketing assitance \& Opinion

\begin{tabular}{|c|c|c|c|c|c|}
\hline & & & \multicolumn{2}{|l|}{ Opinion } & \multirow[b]{2}{*}{ Total } \\
\hline & & & satisfied & Dissatisfied & \\
\hline \multirow{4}{*}{$\begin{array}{l}\text { Marketing } \\
\text { Assistance }\end{array}$} & \multirow{2}{*}{$\begin{array}{l}\text { Rural } \\
\text { entrepreneurs }\end{array}$} & Count & 5 & 45 & 50 \\
\hline & & $\begin{array}{l}\% \text { within Marketing } \\
\text { assistance }\end{array}$ & $10.0 \%$ & $90.0 \%$ & $100.0 \%$ \\
\hline & \multirow[t]{2}{*}{ Artisans } & Count & 3 & 47 & 50 \\
\hline & & $\begin{array}{l}\% \text { within Marketing } \\
\text { assistance }\end{array}$ & $6.0 \%$ & $94.0 \%$ & $100.0 \%$ \\
\hline \multirow[t]{2}{*}{ Total } & & Count & 8 & 92 & 100 \\
\hline & & $\begin{array}{l}\% \text { within Marketing } \\
\text { assistance }\end{array}$ & $8.0 \%$ & $92.0 \%$ & $100.0 \%$ \\
\hline
\end{tabular}

\section{Analysis}

\begin{tabular}{|l|l|l|l|}
\hline & Result & DF & Sig. (2-sided \\
\hline "Pearson's- ChiSquare" & $0.543^{\mathrm{a}}$ & 1 & 0.461 \\
"Likeli -hood- Ratio" & 0.136 & 1 & 0.712 \\
"Linear relation" & 0.549 & 1 & 0.459 \\
"No. of Valid -Cases" & & & \\
"Pearson's- ChiSquare" & 0.538 & 1 & 0.463 \\
"Likeli -hood- Ratio" & 100 & & \\
\hline
\end{tabular}

From the table, the calculated value was 0.543 , and the tabular value was $0.461 \chi$ is greater than $\mathrm{p}$, hence $\mathrm{H} 1$ is accepted

4) Ho: There is an relationship between rural entrepreneurs \& Artisans regarding Training and Development 
H1: There is no relationship between rural entrepreneurs and Artisans regarding Training and

Development

Table 4.1 Cross tabulation of Training and development \& Opinion

\begin{tabular}{|c|c|c|c|c|c|c|}
\hline & \multicolumn{4}{|c|}{ Opinion } & \multirow[b]{2}{*}{ Total } \\
\hline & & poor & Quite good & Good & Excellent & \\
\hline \multirow{3}{*}{$\begin{array}{l}\text { Training\& Rural } \\
\text { Development entreprene } \\
\text { urs }\end{array}$} & Count & 5 & 15 & 25 & 5 & 50 \\
\hline & $\% \quad$ within & $10.0 \%$ & $30.0 \%$ & $50.0 \%$ & $10.0 \%$ & $100.0 \%$ \\
\hline & $\begin{array}{l}\text { Training } \\
\text { Programme }\end{array}$ & & & & & \\
\hline Artisans & Count & 4 & 21 & 22 & 3 & 50 \\
\hline & $\begin{array}{l}\% \quad \text { within } \\
\text { Training } \\
\text { Programme }\end{array}$ & $8.0 \%$ & $42.0 \%$ & $44.0 \%$ & $6.0 \%$ & $100.0 \%$ \\
\hline \multirow[t]{2}{*}{ Total } & Count & 9 & 36 & 47 & 8 & 100 \\
\hline & $\begin{array}{l}\% \quad \text { within } \\
\text { Training } \\
\text { Programme }\end{array}$ & $9.0 \%$ & $36.0 \%$ & $47.0 \%$ & $8.0 \%$ & $100.0 \%$ \\
\hline
\end{tabular}

Table 4.2 Results of chi square

Results of chi square

\begin{tabular}{|l|l|l|l|}
\hline & Result & DF & Sig. (2-sided \\
\hline "Pearson's- ChiSquare" & $1.803^{\mathrm{a}}$ & 3 & 0.614 \\
"Likeli -hood- Ratio" & 1.813 & 3 & 0.612 \\
"Linear relation" & 0.606 & 1 & 0.436 \\
"No. of Valid -Cases" & 100 & & \\
\hline
\end{tabular}

\section{Analysis}

From the table, the calculated value was 1.803 , and the tabular value was $0.614 \chi$ is greater than $\mathrm{p}$, hence $\mathrm{H} 1$ is accepted
5) Ho: There is an relationship between rural entrepreneurs and Artisans regarding Financial assistance

H1: There is no relationship between rural entrepreneurs and Artisans regarding Financial assistance

\section{Table 5.1 Cross tabulation of Financial assistance \& Opinion}

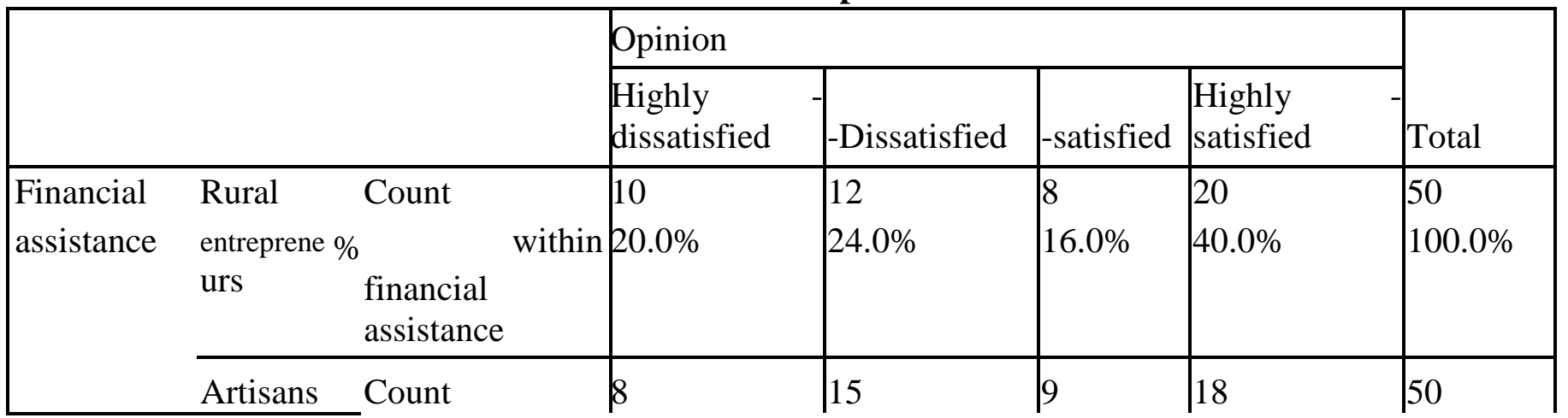




\begin{tabular}{|ll|l|l|l|l|l|}
\hline & $\begin{array}{l}\% \quad \text { within } \\
\text { Training } \\
\text { Programme }\end{array}$ & $16.0 \%$ & $30.0 \%$ & $18.0 \%$ & $36.0 \%$ & $100.0 \%$ \\
\hline Total & $\begin{array}{l}\text { Count within } \\
\% \quad 18.0 \%\end{array}$ & $27.0 \%$ & $17.0 \%$ & $38.0 \%$ & $100.0 \%$ \\
& $\begin{array}{l}\text { Training } \\
\text { Programme }\end{array}$ & & & & & \\
\hline
\end{tabular}

Table 5.2 Results of chi square

\begin{tabular}{|l|l|l|l|}
\hline & Result & DF & Sig. (2-sided \\
\hline "Pearson's- ChiSquare" & $0.720^{\mathrm{a}}$ & 3 & 0.869 \\
"Likeli -hood- Ratio" & 0.721 & 3 & 0.868 \\
"Linear relation" & 0.008 & 1 & 0.931 \\
"No. of Valid -Cases" & 0100 & & \\
\hline
\end{tabular}

\section{Analysis:}

From the table, the calculated value was 0.720 and the tabular value was $0.869 \chi$ is less than $\mathrm{p}$, hence $\mathrm{HO}$ is accepted
6) Ho: There is an relationship between rural entrepreneurs \& Artisans regarding Welfare activities

H1: There is no relationship between rural entrepreneurs \& Artisans regarding Welfare activities

Table 6.1 Cross tabulation of welfare activities \& Opinion

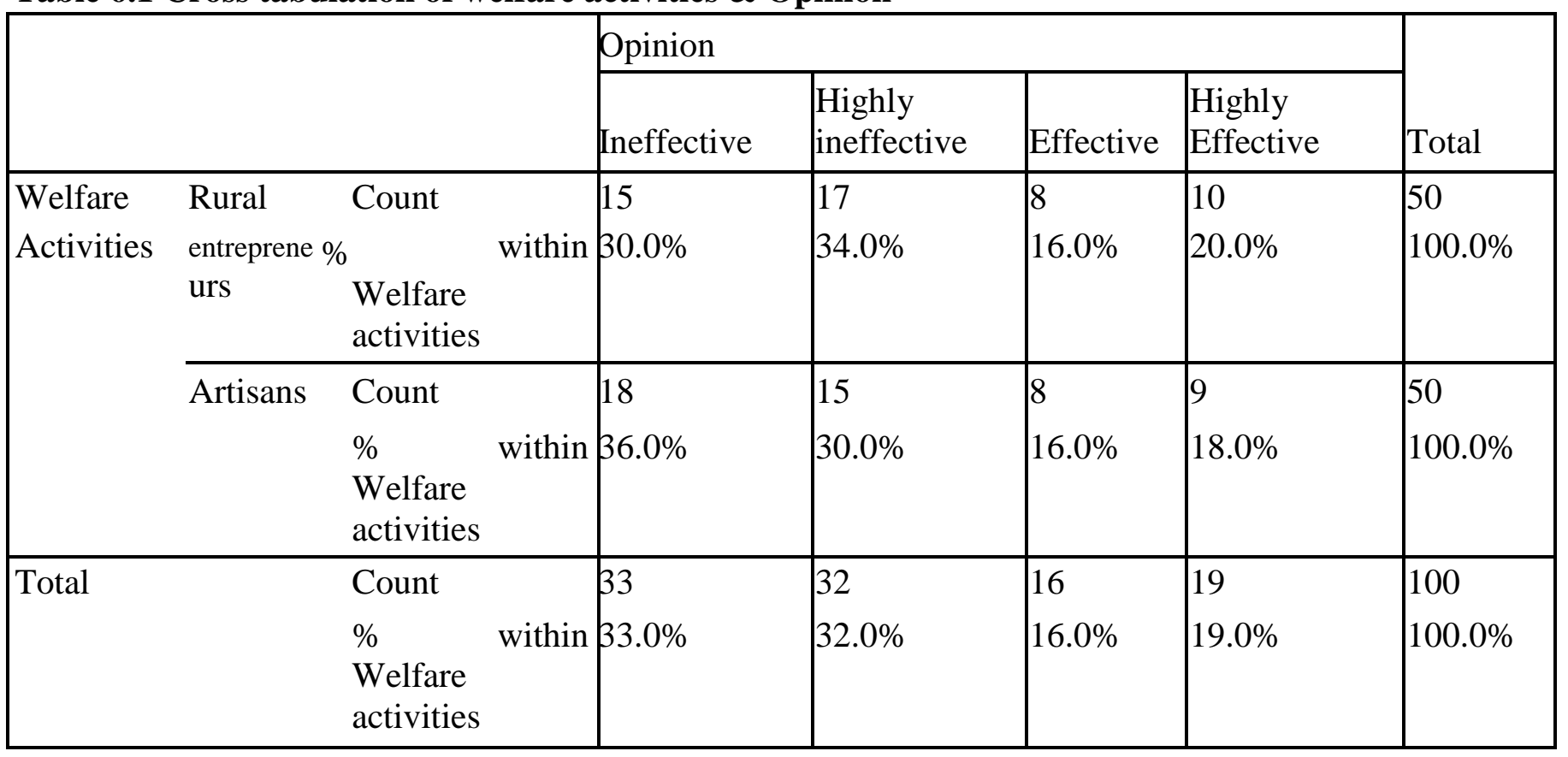


Table 6.2 Results of chi square

Results of chi square

\begin{tabular}{|l|l|l|l|}
\hline & Result & DF & . (2-sided) \\
\hline "Pearson's- ChiSquare" & $0.450^{\mathrm{a}}$ & 3 & 0.930 \\
"Likeli -hood- Ratio" & 0.451 & 3 & 0.930 \\
"Linear relation" & 0.205 & 1 & 0.651 \\
"No. of Valid -Cases" & 100 & & \\
\hline
\end{tabular}

\section{Analysis}

From the table, the calculated value was 0.450 and the tabular value was $0.930 \chi$ is less than $\mathrm{p}$, hence $\mathrm{HO}$ is accepted

\section{RECOMMENDATIONS AND CLOSURE:}

In India's economic growth, rural entrepreneurship plays a vital role in the rural economy. It helps to create job offers in low-capital rural areas, to raise people's real incomes, to contribute to agricultural growth by reducing disguised unemployment, poverty reduction, migration, economic inequality and unemployment. In order to uplift rural areas, the government should assess rural entrepreneurship growth schemes and programs. Because of a lack of capital accumulation, risk taking and creativity, rural entrepreneurship finds it hard to take off. Rural development programs ad development of artisans can develop health care, education, , investment in farming and the promotion of various programmes.

\section{References}

[1] Dr.K.Narendra Kumar, MrsP.Kalpana, "C orporate Social Responsibility And Sustainability," International Journal of SocialSciences\&Humanities (IJSSH),Volume5 Issue 9, pp:97-102 june 2019 ISSN (Online) : 2395-5996 ISSN (Print) : 2454-275X.

[2] Mr.K.Murali Krishna, Dr.K.Narendra Kumar and Mr.P.Ramaswamy, "A Study on Andhra Pradesh State Financial Corporation - An Overview", GEC'S International journal of Innovation Technology and Management, Volume V,
Issue I, February 2019, ISSN: 2394594X.p.p:44-48,Impact factor:2.174.

[3] K.Narendra Kumar, Mrs G.V.Sravya,"Perception of students on purchasing and use of smart phones-A study in Bhimavaram town", Indian Journal of Commerce and management (IJOCAM) volume 3 issue 5 , May-2016, ISSN- 2348-4934(P), 2348-6325(O).

[4] K.Narendra Kumar, Mr.K.Rambabu, "Role of SHG's In Rural Development In Andhra Pradesh", International Journal of Social Sciences \& Humanities (IJSSH), Volume 1 Issue 1 April 2015, ISSN (Online) : 23955996.

[5] K. Narendra Kumar, Dr.Varsha S.Sukhadeve, "Role of Self Help Groups in Empowering Rural Women A Study in Godavari Districts, Andhra Pradesh", International Journal of Advances in Arts, Sciences and Engineering, Volume 2 Issue 5 July 2014 ISSN: 2320-6136(Print), 2320-6144 (Online).

[6] K.Ganga Raju \& D.Leela Kalyani, "Rural Entrepreneurship-Opportunitiesand Challenges" GEC's International Journal of Innovation, Technology and Management, With ISSN:2394-594X, Vol6, Issue 1, 1st February 2020, PP:1013

[7] K.Ganga Raju, Role of Yoga in System Management", published in International Journal of Health, Physical education, and computer science in sports, Volume: 26, Issue no: 2, Page no: 112-117, June 2017.

[8] K.Ganga Raju, "Women Entrepreneurship: Ambitions, Aspirations \& Attitudes" 
published in International Journal of Entrepreneurship and Business Environment Perspectives with ISSN (online):2279-0926, Volume6, Number:1 (January to March,2017), pp.30313038,Pezzottaite Journals.

[9] D.Vijaya Lakshmi \& K.Ganga Raju "Effective Cross Cultural Communication" published in International Journal of Science Technology and Management (IJSTM, ISSN-2394-1537, vol.No.4, Issue 11, November 2015)

[10] K.GangaRaju, “ThePrinceof

Entrepreneurship: Steve Jobs," published in Kaav International Journal of Economics, Commerce \& Business Management, ISSN: 2348-4969 with Impact Factor (2015) - 3.9581, Dt.21.8.2015.

[11] K.Ganga Raju, "Factors Motivating Women Entrepreneurs (A Case Study of Selected Women Entrepreneurs in Bhimavaram Town, Andhra Pradesh)", Published in Mc Stanford Journal of International Management, ISSN: 23211652, December 2014. 